\title{
Ice and Ivory: the cryopolitics of mammoth de-extinction
}

\author{
Charlotte Wrigley ${ }^{1}$ \\ Higher School of Economics, Russia
}

\begin{abstract}
Woolly mammoth tusk hunting has become a black-market industry in the Siberian region of Yakutia, where thawing permafrost due to climate change is revealing the bodies of thousands of mammoths. They are often in a state of incredible preservation, and their accompanying tusks can be sold to China where they are carved into ornaments as a marker of status. Alongside tusk hunting, another potential industry has emerged: deextinction. Many of the mammoths found on the tundra have potentially viable DNA that might be used to resurrect a mammoth through genetic technology. Mammoth de-extinction is a cryopolitical process - a focus on the preservation and production of life at a genetic level through cold storage. 'Cryobanks' have emerged as a way to safeguard endangered and extinct species' genetic material, and forms part of a turn towards preempting conservation crises during what some scholars are calling the 'sixth great extinction.' The mammoth's body is broken down into pieces - tusks form luxury commodity chains, whilst flesh and blood is parceled into frozen genes and cells. The mammoth in the freezer is indicative of a reorganization of cold life in a warming world, with the specific cryopolitics found in the cryobank an attempt at extending human control over planetary processes that are now seemingly out of control. Drawing on fieldwork undertaken at the Mammoth Museum in Yakutsk, Siberia, and at the Natural History Museum's cryobank in London, I follow the mammoth from permafrost, to freezer, to back outside, and consider how her de-extinction is a response to a particular sort of future crisis - that of our own extinction.
\end{abstract}

Key Words: De-extinction; permafrost; Arctic; cryopolitics; rewilding

\section{Résumé}

La chasse aux défenses de mammouth laineux est devenue une industrie de marché noir dans la région sibérienne de Yakoutie, où le dégel du pergélisol dû au changement climatique révèle les corps de milliers de mammouths. Ils sont souvent dans un état de conservation incroyable, et leurs défenses peuvent être vendues en Chine où elles sont sculptées en ornements comme marqueur de statut. Une autre industrie potentielle a maintenant émergé : la " dé-extinction ». Certains des mammouths trouvés dans la toundra ont un ADN potentiellement viable qui pourrait être utilisé pour ressusciter un mammouth grâce à la technologie génétique. La désextinction des mammouths est un processus cryopolitique - la préservation et la production de la vie à un niveau génétique grâce à l'entreposage au froid. Les « cryobanques » sont apparues comme un moyen de sauvegarder le matériel génétique des espèces menacées et éteintes. Ils font partie des efforts visant à éviter les crises de conservation pendant la soi-disant «sixième grande extinction ». Le corps du mammouth est décomposé en morceaux - les défenses forment des chaînes de produits de luxe, tandis que la chair et le sang sont fragmentés en gènes et cellules congelés. Le mammouth dans le congélateur est révélateur d'une réorganisation de la vie froide dans un monde en réchauffement, et la cryopolitique spécifique trouvée dans la cryobanque est une tentative d'étendre le contrôle humain sur des processus planétaires qui sont maintenant apparemment hors de contrôle. En m'appuyant sur des travaux de terrain entrepris au Mammoth Museum à Yakutsk, en Sibérie, et à la cryobanque du Natural History Museum à Londres, je suis le mammouth du

\footnotetext{
${ }^{1}$ Dr. Charlotte Wrigley, Postdoctoral Research Fellow, Laboratory of Environmental and Technological History, Higher School of Economics (Высшая школа экономики), Saint Petersburg, Russia. Email: cwrigley "at" hse.ru. Acknowledgements: thanks to two reviewers, editors Bram Büscher and Ananda Siddhartha, Dr. Julia Loginova for the Russian translation, and the participants at the Crisis Conservation workshop held from 5-9 October 2020. This work was funded by the Economic and Social Research Council, UK. This is the fifth article in B. Büscher (ed.). 2021. "Political ecologies of extinction", Special Section of the Journal of Political Ecology 28(1): 696-888.
} 
pergélisol, au congélateur, jusqu'à l'extérieur. Je considère comment sa désextinction est une réponse à un type particulier de crise future - celle de notre propre extinction.

Mots clés: Dé-extinction; permafrost; Arctique; cryopolitique; ré-ensauvagement

\section{Resumen}

La caza de colmillos de mamut lanudo se ha convertido en una industria del mercado negro en la región siberiana de Yakutia. El deshielo del permafrost está dejando al descubierto los cuerpos de miles de mamuts. A menudo están muy bien conservados, y sus colmillos pueden venderse a China, donde se tallan en forma de adornos como marcador de estatus. Ha surgido otra industria potencial: la de la desextinción. Mamuts con ADN potencialmente viable que podría utilizarse para resucitar un mamut mediante tecnología genética. Se trata de un proceso "criopolítico", centrado en la conservación y producción de vida a nivel genético mediante el almacenamiento en frío. Los "criobancos" han surgido como una forma de salvaguardar el material genético de especies extinguidas y en peligro de extinción, y un esfuerzo por evitar la "sexta gran extinción" y las crisis de conservación. El cuerpo del mamut se descompone en trozos: los colmillos forman parte de las cadenas de productos de lujo, mientras que la carne y la sangre se parcelan en genes y células congeladas. El mamut en el congelador es indicativo de una reorganización de la vida fría en un mundo que se calienta. La criopolítica específica del criobanco es un intento de ampliar el control humano sobre los procesos planetarios que ahora parecen estar fuera de control. Basándome en el trabajo de campo realizado en el Museo del Mamut de Yakutsk (Siberia) y en el criobanco del Museo de Historia Natural de Londres, sigo al mamut desde el permafrost hasta el congelador y de nuevo al aire libre. Considero que su desextinción es una respuesta a un tipo particular de crisis futura: nuestra propia extinción.

Palabras clave: Desextinción; permafrost; Ártico; criopolítica; rewilding

\section{Абстракт}

Охота на бивень шерстистого мамонта превратилась в отрасль черного рынка в сибирской Якутии, где таяние вечной мерзлоты из-за изменения климата обнажает тела тысяч мамонтов. Они часто находятся в состоянии невероятной сохранности, и их бивни могут быть проданы в Китай, где украшения из кости служат индикатором общественного статуса. Наряду с охотой на бивень возникла еще одна потенциальная отрасль: де-вымирание. Многие из мамонтов, найденных в тундре, имеют потенциально жизнеспособную ДНК, которая может быть использована для воскрешения мамонта с помощью генетических технологий. Де-вымирание мамонтов - это криополитический процесс, в котором основное внимание уделяется сохранению и производству жизни на генетическом уровне посредством холодного хранения. «Криобанки» возникли как способ защиты генетического материала исчезающих и вымерших видов и являются частью поворота к предотвращению природоохранных кризисов во время того, что некоторые ученые называют «шестым великим вымиранием». Тело мамонта разбивается на части: бивни образуют сети товаров роскоши, а плоть и кровь разделяются на замороженные гены и клетки. Мамонт в морозильной камере свидетельствует о реорганизации холодной жизни в теплеющем мире, при этом специфическая криополитика криобанка является попыткой расширить человеческий контроль над планетарными процессами, которые теперь как кажется вышли из-под контроля. Опираясь на полевые исследования в Музее Мамонта в Якутске, в Сибири, и в криобанке Музея Естественной Истории в Лондоне, я следую за мамонтом, от вечной мерзлоты до морозильной камеры и обратно, и рассматриваю, как де-вымирание мамонта является ответом на особый вид будущего кризиса - кризиса нашего собственного вымирания.

Ключевые слова: де-вымирание; вечная мерзлота; Арктика ; криополитика; возрождение дикой природы

\section{Introduction}

The region of Yakutia in North-East Russia is the size of India but has a population akin to that of Belgium. It is also one of the coldest inhabited places on Earth, with its capital Yakutsk regularly registering temperatures of $-50^{\circ} \mathrm{C}$, and much of its Northern tundra reaches lying beyond the Arctic Circle. Almost all its landmass is permafrost - that is, soil that is permanently frozen. Lately, however, things have been changing: record high temperatures in the summer months, wildfires raging through the larch forests of the taiga, permafrost thawing, the ground slumping and buckling, causing huge damage to the infrastructure that was 
built on the assumption the ground would remain stable - permanently. Meanwhile, in March 2020, the Russian government published a new Arctic strategy which set out a hugely ambitious - and destructive - plan for exploiting the region's vast resources: an Arctic shipping route that banks on an ice-free Arctic Ocean, plans for oil and liquid natural gas extraction, plus the infrastructure necessary to facilitate it (Putin, 2020). The situation in the Russian Arctic encapsulates the fundamental paradox of the proposed new geological epoch of the Anthropocene: that humans are now the dominant geologic agent that affects Earthly processes, but the consequences of those actions are threatening human - and other species' - survival on the planet.

Every summer, groups of men - mostly Indigenous - head deep into the Yakutian tundra and likely will not return until the autumn. They are after the ivory from mammoth tusks, once locked deep within frozen permafrost, now becoming more and more accessible with increased thaw. There are officially sanctioned tusk hunts, but most of the hunters operate illegally with the use of a high-powered water canon to blast through mushy permafrost and make tunnels. These tunnels are dangerous, liable to subsidence and mudslides, but the deeper they go, the greater the chances to strike white gold. A single tusk can sell for eye-watering amounts, travelling from tusk hunter to buyer to Chinese markets, carved into ornaments, shaped into jewelry, displayed in homes as markers of status. ${ }^{2}$ Hunters who find big, intact tusks can expect riches far beyond the average monthly salary of Yakutia (around US\$500); hunters who find nothing - most of them - will more than likely lose money. Tusk hunting is a gamble, but the allure of striking it big is enough to see hunters return summer after summer.

Tusk hunters are not the only ones on the lookout for wooly mammoths (Mammuthus primigenius). The controversial new science of de-extinction purports that extinction no longer be forever; as long as genetic material exists in a form that is not highly degraded, it is possible to resurrect - in theory - extinct species, either by cloning an intact cell, or by a process of hybridization that plugs the genetic features of the extinct creature into the genome of a taxonomically similar one (Shapiro, 2016). There are currently two main laboratories actively working on de-extinction science: geneticist George Church's laboratory at Harvard University, which uses CRISPR technology to cut and splice genes ${ }^{3}$, and Sooam Biotech in Seoul which is following the cloning method. The mammoth is one of the top candidates for de-extinction, despite having been extinct for several thousand years; the reason mammoth DNA has not degraded to the point of uselessness for de-extinction is because it has been preserved by permafrost. Ultimately, the goal is to return a de-extincted mammoth to her former territory in Siberia. ${ }^{4}$ A rewilding project on an isolated patch of tundra in NorthEastern Yakutia is attempting to restore the prehistoric 'mammoth steppe' ecosystem. Called the Pleistocene Park in a nod towards pop-culture's most famous de-extinction project, the idea is to mitigate permafrost thaw by way of large herbivores trampling the soil to keep it frozen, stimulating a grassland that reflects solar radiation. Ironically, it is the thawing of permafrost that reveals these mammoths - sometimes in the form of almost whole bodies, so well preserved they look as if they are sleeping. As the ground slumps and collapses in on itself, mammoth flesh is exposed to air that rots and degrades.

To counter the destructive outcome of melting - and, indeed, warming in general - DNA must be preserved through artificial freezing systems. Conservationists are increasingly turning to frozen safeguards as a sort of stopgap solution until better technology or resources become available (Edesi et al., 2020). This is largely a response to a biodiversity crisis that some ecologists are calling the 'sixth great extinction' - the first one attributed to human activity (Ceballos et al., 2015) - and might be termed 'crisis conservation.' Putting species DNA and genetic material 'on ice' acts to diffuse the fraught immediacy of endangered species

\footnotetext{
${ }^{2}$ Carved ivory ornaments are a status symbol in China and the country occupies the dubious honour of being the world's largest ivory trade (Myers, 2017). After its 2018 elephant ivory ban, the Chinese market turned to mammoth ivory to plug the gap. Whilst this move may have had a positive impact on elephant poaching elsewhere in the world, the forces of capitalism make themselves known in other arenas - in this case, the thawing permafrost of Siberia by which the mammoth's body is renegotiated as a luxury commodity.

${ }^{3}$ CRISPR is a gene editing software that hugely speeds up the process of sequencing and splicing genes. Such has been CRISPRs meteoric rise in popularity, it is now possible to purchase home CRISPR kits for biohacking yourself.

${ }^{4}$ I purposely gender the 'Siberian mammoth' as female, partly due to the fact the most important mammoth body to deextinction research - Buttercup - is female, but also as a way to point to the masculine nature of de-extinction science and the task of the first de-extincted mammoth to begin a cycle of reproduction and birth.
} 
conservation and extinction, mute the nagging anxiety that it may be too late, and offer a get-out clause - be that through captive breeding or the potential for de-extinction. This is a strategy orientated not only towards the conservation of species, but also the conservation of time, made possible by the temporal plasticity offered by the freezer - or, more accurately, a cold storage facility for genetic material called a cryobank. Cryobanks are part of a wider process of what scholars are calling 'cryopolitics' - the political renegotiation and manipulation of life through coldness (Bravo, 2017; Radin and Kowal, 2017).

For this reason, tusk hunters are often used by scientists for tip-offs on mammoth bodies. Once the precious tusks have been removed, their festering corpses can be salvaged and transported to freezers where they can be hacked apart further in the pursuit of 'useable' DNA. That the quite patently dead mammoth bodies contextualized by thousands of years of extinction now exhibit a sort of liveliness speaks to a moment of crisis that is both apparent in conservation and across the planet itself. Resurrecting the mammoth is indicative not just of a biopolitical desire for mastery over life, but also as tool to prolong human survival on an increasingly hostile planet. How this process occurs in practice is underscored by a broader commodification and renegotiation of life at the cellular level, made possible by new technologies of freezing. The viability of deextinction is a cryopolitical transaction that sees the threat to life due to global warming become stabilized by human methods of cryopreservation - ostensibly cementing the notion that the Anthropocene designates a sense of human mastery over natural processes through technological prowess.

This article sits at the intersection between a variety of vested interests regarding the woolly mammoth and her potential as a de-extinction candidate. What draws these interests and interventions together is coldness, and the processes of freeze and thaw that make the mammoth visible, possible, and valuable. How does temperature figure in these new forms of crisis conservation, as thawing permafrost produces both climate anxiety and capitalist potential? And how does a cryopolitics of coldness renegotiate boundaries of life and death, extinction and resurrection, control and commodity? These questions are answered using data from two fieldwork stints to Yakutia, Russia - the first comprising one month spent at the Pleistocene Park north of the Arctic circle, the second three months in Yakutsk, home of the Mammoth Museum. It draws from a combination of in-person interviews with key actors in cryobanking, de-extinction and tusk hunting practices, participant observation, and discourse analysis of popular media around de-extinction and the Pleistocene Park. In order to provide a historical context to the current situation of mammoth conservation, I first trace a number of mammoth histories which follows the trajectory of the mammoth's status from museum specimen to genetic material; the next section considers the fraught space of the 'outside' where mammoths are discovered by tusk hunters in thawing permafrost, and the anxieties of extinction generated through increasing temperatures; then, I enter the cryobank to examine how freezing suspends and preserves life, producing a reimagining of preemptive conservation practices that values the life - or resurrection - of the mammoth as future capital; the final section imagines the resurrected mammoth out in the world again, and argues that the de-extinction of the mammoth is not only indicative of cryopolitical control over nonhuman life during the sixth great extinction, but also a novel 'crisis conservation' of the human species at a time when rising temperatures threaten our survival.

\section{De-extinction and the cryopolitics of molecular life}

Cryobanking and de-extinction are part of a broader renegotiation of life from holistic individual units to the level of the gene - a process which began with the discovery of the gene at the beginning of the $20^{\text {th }}$ century and dubbed "the molecularisation of life" by Foucauldian theorist Nikolas Rose (2001; 2007). This reconfiguration promoted by biological and biomedical institutes also served to 'optimize' and control these processes, with new forms of technoscience becoming embedded within the promotion of life at the molecular level (Braun, 2007; Parry, 2006). The notion of the gene as a bounded entity which contained the long-obscured secrets of life itself was an incredibly attractive and easily graspable idea, taking root in the popular imagination and spawning countless scientific interrogations (Fox-Keller, 2002; Kay, 2000; Fletcher, 2020; Rossi, 2013). In the latter stages of the $20^{\text {th }}$ century, genetic biology shifted its attention to entire genomes, and began to sequence the genomes of different species with varying genetic complexities: the human was completed in 
2003 as part of the ground-breaking 'human genome project'; the mammoth over a decade later in 2015, and the first extinct genome to be sequenced (Palkopoulou et al., 2015).

The gene is not merely an abstract unit of life, but also a form of commodifiable matter. The encroaching forces of neoliberalisation and privatization work together to decide which genetic material and research is privileged over others, producing a form of molecular biopolitical governance (Mendes, 2017; Thacker, 2005). This aligns with the academic use of the term 'biocapital', in which biological materials take on commodity value once they are extracted from organic bodies through biotechnologies (Cooper, 2008; Parry, 2004, 2006; Shukin, 2009). Biomedical theorist Catherine Waldby identifies this trend through what she calls 'biovalue', stating that dissection of corpses represents "the mining of death to increase the value and productivity of life, its technical augmentation" (2000: 142). The extinct mammoth remains dead, in the normative understanding of the term, but her increasing biovalue through sliced and diced body parts produces a certain liveliness underpinned by how attractive these pieces are as commodities. Body parts and cells circulate across boundaries that are becoming increasingly porous due to the fungible nature of biological material taken out of its environmental milieu (Rajan, 2006). In particular, the push for the mammoth's de-extinction places particular emphasis on the genome, and the ability of laboratory tissue cultures to be controlled and manipulated outside the individual living body (which, of course, no longer exists). The genetic features that 'make' a mammoth - shaggy fur, small ears, cold-adapted blood - take on a greater value than the sum of their parts; it is only by replicating these species indicators that a mammoth might be said to be resurrected through hybridization. And similarly, in the case of cloning efforts, the hunt for the intact cell plucked from the decaying body of a dead mammoth becomes the locus of life - the possibility of coaxing cell reproduction in a laboratory that might one day restore an entire species from extinction.

Instead of focusing on living and viable populations, the race now becomes one of gathering salvageable genetic material, either for use in captive breeding or artificial insemination programs, or as safeguards for future de-extinction schemes (Breithoff and Harrisson, 2018). These repositories of cells, genes, pieces of flesh or plant life, then take on an altered state as frozen life, suspended and catalogued until it is needed at a later date. Called cryobanks, they have been referred to as "future-making institutions" (Harrison: 2017), and producers of "latent futures" (Radin, 2016). This is indicative of a new form of biopolitics enabled by the freezer - that of a cryopolitics - in which the life in question is now not allowed to die and is kept in a form of stasis until further decisions can be made on its viability (Kowal and Radin, 2017). Freezing technologies make possible the malleability and extension of life at the genetic level, with the most advanced freezing techniques (currently liquid nitrogen) allowing frozen material to endure indefinitely. Biotechnology sociologist Hannah Landecker uses the notion of plasticity in the freezer to identify what she terms 'the thread of life' - the idea that cells outside of the mortal individual body become continuously linked across boundaries of sex, species, and even time: "It is the new form of immortality built into scientific life - disembodied, distributed continuity" (2007: 176).

Cryopolitics does not just encompass the rise in human freezing systems, it also points to the ways in which life is entangled with coldness as a precondition of being - a precondition which is becoming ever more threatened by a rapidly warming world and a meteoric rise in species extinction (Bravo, 2017). Political ecologists call for greater attention to be paid within the remit of their approach to shifting biopolitical practices of conservation (Büscher, 2018; Cavanagh, 2018), and I wish to answer this call with a focus on the ways the melting of ice and the switching on of the electric freezer configure and reconfigure life. Geographer Bram Büscher draws on Brian Massumi's notion of 'ontopower', in which he highlights how the aims of conservation are being renegotiated as pre-emptive measures in a world beset by crises of extinction (Büscher 2018). Cryopolitics is therefore a new kind of ontopower, in that the ability to suspend and preserve life and time through freezing produces new temporalities of pre-emption, highlighting the ways in which cryobanking renegotiates the political life of the specimen. Precision conservation, in general, has seen a shift to the molecular as a response to the anxieties of the Anthropocene (Adams, 2017; Rossi, 2013). The proliferation of cryobanking facilities for endangered and extinct species of non-human suggests that the overall health of animal and plant populations are now also being negotiated at the level of the gene - a shift that mirrors the 
molecularisation of life (Rose, 2001; 2007). And of course, it is not merely cryobanks who are engaging with molecular conservation; Sooam Biotech and the George Church lab practice their de-extinction efforts through the use of frozen cells, genes and DNA. This is a brand-new type of conservation work, in which the difficult realization is that perhaps there will not be time, at least right now, to save some of the most critically endangered species in the sixth great extinction (Lermen et al., 2009).

The mammoth's status as a de-extinction candidate occupies a new kind of cryopolitics: one that aims to produce and maintain control over the life of an extinct species, but as an auxiliary to the renegotiation of power over cold human life. Refreezing the mammoth renders her broken down into the molecular, her genetic life parceled as commodities to be exchanged or sold, and her potential de-extinction into a creature that can rewild an ecosystem for the benefit of human survival. This is different to the trend towards a more neoliberal conservation through which the mammoth becomes monetized (Brockington et al., 2008; Büscher et al., 2012), although occasionally, and not helped by the Pleistocene Park's tongue-in-cheek nod towards its Jurassic counterpart, there is talk about a future of mammoth safari holidays (Andersen, 2017). The Pleistocene Park commodifies the de-extincted mammoth through all manner of promotional material and targeted visions of a fully functioning ecosystem with the mammoth at the helm to attract funding and donations ${ }^{5}$; journalists and filmmakers drawn to the fantastical nature of the project similarly bolster this vision with jaw-dropping vistas and narratives of pioneering human ingenuity (Andersen, 2017; Slater, 2017; Sneguirev, 2020). Yet dig deeper and this is no typical rewilding project - this rewilding project claims it will save the world. Notwithstanding the hyperbolic language emerging from what is still just a local project, the Pleistocene Park exists as a geoengineering strategy not for the conservation of animals, but for the conservation of humanity. Permafrost thaw releases greenhouse gases into the atmosphere, exacerbating climate change and thus threatening human survival; meanwhile, the proliferation of apocalyptic narratives in popular news reporting and media, indicate the notion of human extinction has become a pressing trope as the planet heats up (Milkoreit, 2017; Sepkoski, 2020).

The following sections will 'follow' the mammoth as she is prospected and dug out of thawing ground, parceled up through a multitude of vested interests, and preserved/conserved across a variety of scales and practices. ${ }^{6}$ Doing this aims to think through these new conservation practices that are predicated on responding to what is seemingly an out-of-control situation (Cunha, 2015) with greater precision and pre-emption. The specific cryopolitics that underpin such practices reveal the power imbalances of curating future life in the Anthropocene. These cryopolitical renegotiations are largely predicated on controlling temperature, shifting the locus of governable life from the uncontrollable outside into the controllable inside of the cryobank. I show how the mammoth embodies this shift at every step and when - if - she emerges back outside, she will be mobilized as a planetary savior not her own species, but for humanity.

\section{Mammoth histories}

The first - at least, the first documented - full frozen mammoth body was found in 1799 by an Evenki hunter called Ossip Schumakov at the mouth of the River Lena. Disregarding the warnings from other Evenki not to disturb the carcass, Schumakov hacked off the tusks and sold them to a merchant in Yakutsk, who presumably spread the word around town about the find. Several years later, these rumors reached the ears of the botanist Mikhail Adams, who led an expedition to exhume the body and bring it back to St. Petersburg. The expedition was mostly a failure, with Adams arriving in August of 1807 to a rotting mammoth corpse, torn

\footnotetext{
${ }^{5}$ The Pleistocene Park has run several crowdfunder campaigns to drum up interest and support in order to help them bring more animals to the Park. Although nothing to do with mammoth de-extinction, these crowdfunders use the likeness of the mammoth in logos and artistic renderings of what the Park with de-extincted mammoths would look like.

${ }^{6}$ My approach draws inspiration from 'follow the thing' literature, although with a strict caveat: much of the criticism levied at this vein of scholarship points to its linearity in favour of ending up in Western markets without considering what goes beyond that (Gregson et al., 2014); my goal here is to scramble any such notions of linearity and instead point to the rather messier and eruptive points along intersecting commodity chains and different scales.
} 
apart by scavengers with the majority of the organs and trunk eaten completely; he was only able to retrieve most of the head and two of the feet which had remained encased in permafrost. However, a big success was the collection of the skeleton, and once back in Yakutsk he was able to procure the creature's tusks from the original buyer. By comparing sketches of the complete carcass drawn by the merchant alongside the oral testimony of Schumakov, he was able to assemble the first ever mammoth skeleton for display to the world (Figure 1). Although not without its errors - the tusks were placed the wrong way - this reconstructed beast became integral to the new paleontological understandings of prehistoric creatures. Georges Cuvier, for example, used the Adams' mammoth as evidence for his theory that this was a distinct (and now extinct) species, and not a sub-population of elephants as originally thought (Rudwick, 2005, 2014). The fact the Adams' mammoth had been found with skin covered in hair proved that it was adapted to living in cold climates. Along with the fossilized remains of mammoths, the Adams' specimen, and the subsequent discovery of other intact bodies in the permafrost, contributed to an understanding of the mammoth's prehistoric habitat, behaviors and eventual extinction - although debate is ongoing whether this was due to Pleistocene Overkill or climate change (Brook and Bowman, 2004).

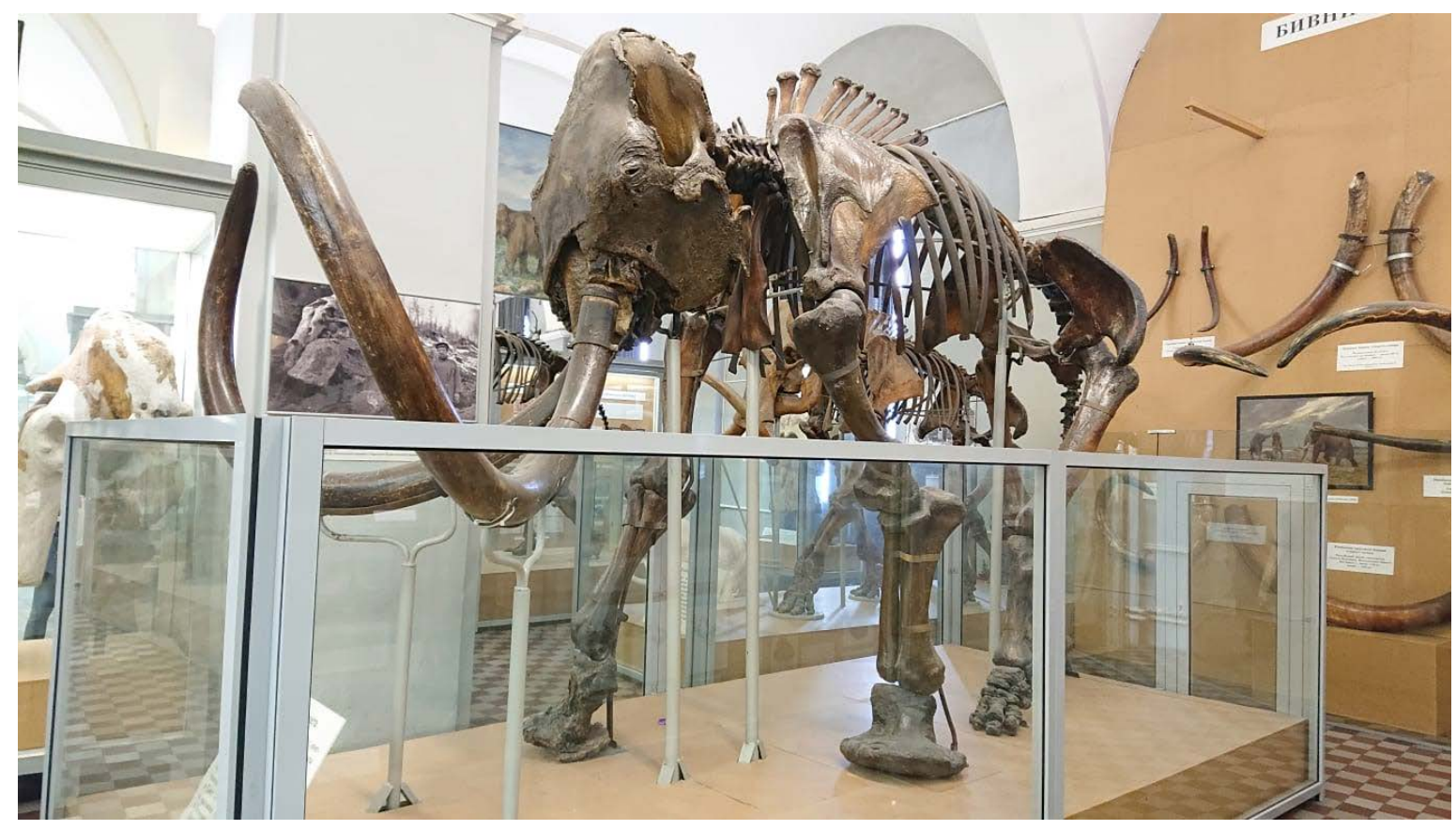

Figure 1: The Adams mammoth. (author's own, 2019)

These mammoth discoveries quickly became objects of curiosity and proliferated in museums and exhibitions: displayed as skeletons, life-size models mocked up with hair, or even the preserved specimens themselves on show. The mummified corpse of a baby mammoth - Dima - was discovered in the Magadan region in 1977, and another baby - Lyuba - was found in even better condition on the Yamal peninsula in 2007, so much so that she still had her mother's milk in her belly. Both Dima and Lyuba travel the world in temperature-controlled crates, put on display in glass cases for the public to marvel at. The Melnikov Permafrost Institute's permafrost cave is home to a plaster cast replica of Dima, having been the storage facility for the body until it was taken to St. Petersburg (Figure 2). Other mammoths have achieved similar fame, not least the Jarkov mammoth, which was the subject of a bizarre expedition led by French explorer Bernard 
Buigues in 1999. Armed with little more than a vague tip-off from a Dolgan boy and a hefty wad of cash, he took a crew into the tundra in an attempt to drill the creature out of the still-frozen permafrost. The Discovery Channel documentary 'Raising the Mammoth' (2000) shows the faintly other-worldly footage of the beast still mostly encased in a block of ice - being winched into the air by helicopter and flown over the snowy landscape to a permafrost cave, where it remains to this day.

Today, mammoth finds are relatively common. Thawing permafrost and a surge in tusk hunters plying their trade in the summer months mean that preserved remains are revealed on a regular basis - either by slumping ground or blasting the permafrost with water cannons. However, not all mammoth finds are created equal. How well preserved the bodies are depends on how quickly the mammoth was frozen in permafrost after death, and how long the corpse was exposed to the degradational effects of air upon discovery. In 2012, a tusk hunter discovered a mammoth - a female nicknamed Buttercup - on Maly Lyakovsky island in the Laptev Sea, off the Arctic coast of Yakutia. The head of the Mammoth Museum in Yakutsk, Semyon Grigoriev, immediately set about forming an expedition team to visit the remains, having been informed of their remarkable preservation in the permafrost (Grigoriev et al., 2017). When the team arrived at the site, they were amazed to find an almost complete mammoth carcass, replete with frozen hair, skin and flesh; in fact, so well preserved was Buttercup that Semyon promptly sliced off a piece of her flesh and ate it. But the most shocking - and jubilant - discovery came when excavators drilled into Buttercup's flesh, which then produced a dark red, sticky substance that flowed out of her side. Whilst no longer containing red blood cells, what Buttercup had produced was a sort of degraded blood, and she was the first mammoth on record to do so. Liquid blood meant that this mammoth was better preserved than any other mammoth ever discovered before; liquid blood meant that - at least potentially, theoretically - Buttercup could be brought back to life.
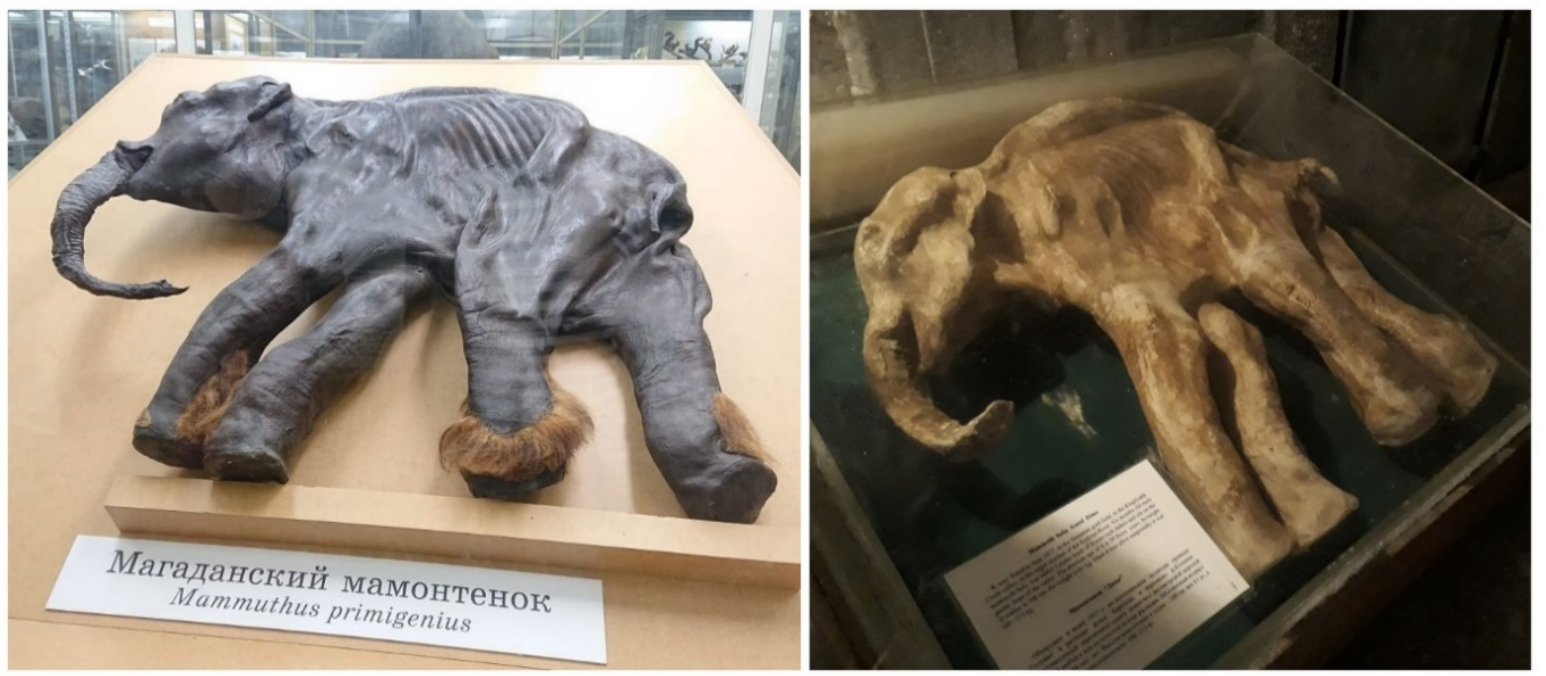

Figure 2: Dima in his glass case at the St. Petersburg zoological museum, and the plaster cast replica at the MPI. (author's own, 2018; 2019)

The Siberian mammoth is now the focus of multiple vested interests. Having lain dormant in the relative peace of extinction, locked away for centuries in a permafrost tomb, she now finds herself the subject of excavations, blasted with water cannons, chopped into pieces and broken down into genes, her tusks shipped off to China and her DNA sent across the world to biotechnology laboratories - Seoul, Osaka and Harvard. Her body is now worth less intact, with the knowledge gleaned from the Adams' mammoth spent and the bodies of Dima and Lyuba now relegated to mere curiosities. Instead, the mammoth's intrigue lies in her future potential, either as riches in the form of carved ivory ornaments, or as viable genetic material for her deextinction. A team of scientists, with representatives from both the George Church lab and Sooam Biotech present, conducted an autopsy on Buttercup in 2014 and took various samples of blood and flesh; whilst her 
tusks were retained by the Mammoth Museum, her body - harvested of any potentially viable genetic material - now lies forgotten in a plastic bag in the corner of the walk-in freezer (Figure 3).

The molecularization of the mammoth into tusks and genes produces new configurations of value as future capital through the new science of de-extinction. She becomes valued as something beyond her individual body and history, and instead represents something broader and more future-oriented through the fungibility that molecularization offers. The mammoth's scientific and popular trajectory throughout history can be correlated with the renegotiation of her status as a material and socio-cultural object: the Adams' mammoth appeared at a point when paleontologists and geologists were grappling with questions of earthly revolution and past extinctions ${ }^{7}$; today, her situatedness within a world of ongoing extinction and climate change means she encapsulates both an engagement with a deep past, but also the anxiety of an uncertain future. As the planet warms and survival rendered increasingly precarious, coldness becomes a valued scarcity: it is at this point the two cryopolitical worlds of the outside (mammoths in thawing permafrost) and the inside (mammoths in the cryobank) converge to produce a new definition of life and extinction - all contained within a drop of blood.

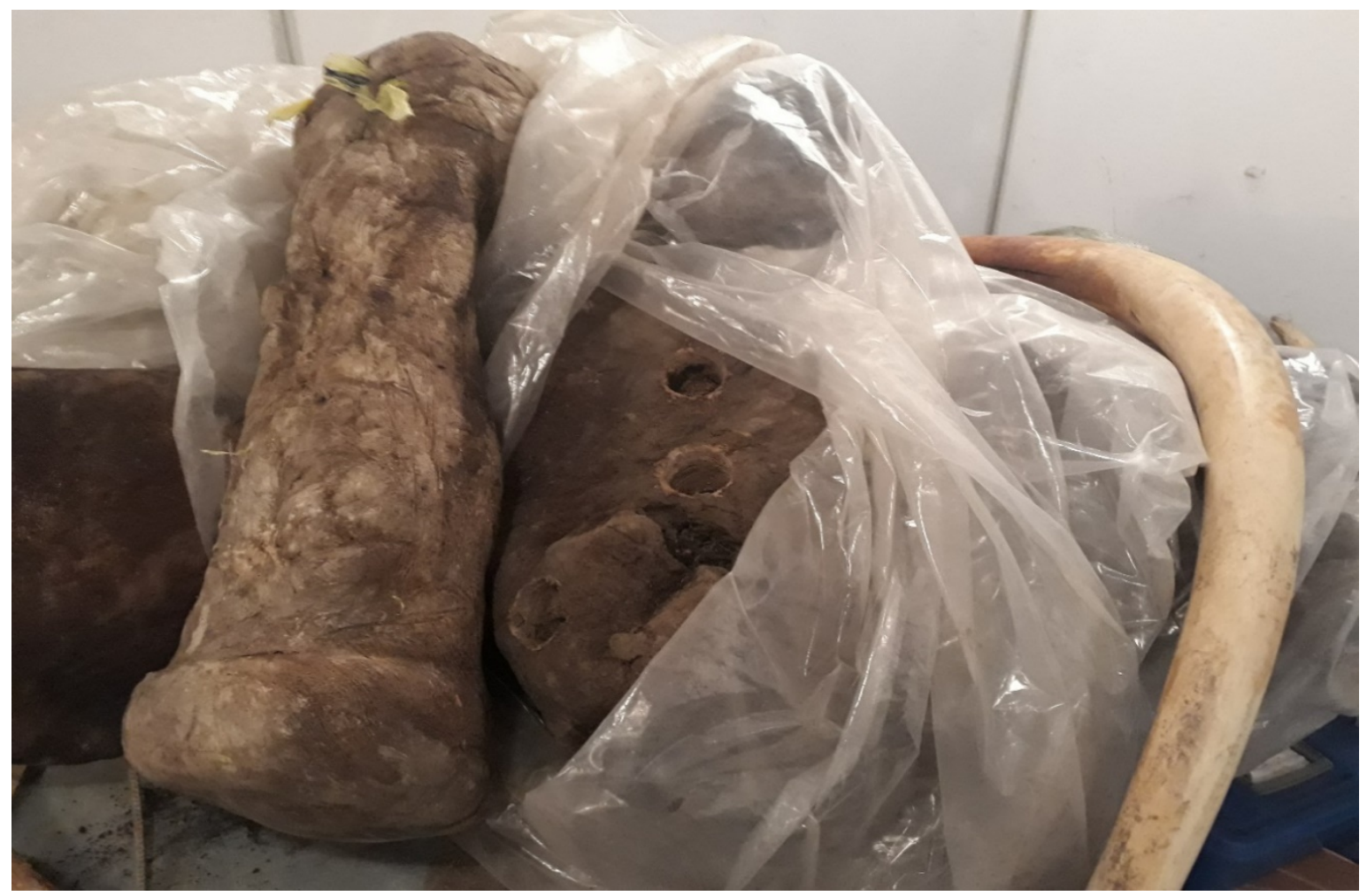

Figure 3: The sad final resting place of Buttercup. (author's own, 2018)

\begin{abstract}
${ }^{7}$ In particular, paleontologist Georges Cuvier's analyses of fossil and carcass discoveries across Siberia drew attention to how certain histories and certain futures become constructed. Having derailed the budding discipline of Western geology with petulant smears and misinformation, as well as subscribing to deeply racist and often downright unscientific beliefs, his ideas around extinction and the remains of extinct species were revolutionary at the time (Rudwick, 2005). His catastrophist thinking and notion of earthly 'revolutions' causing massive and sudden upheaval to planetary life was not particularly original, but his dogged pursuit of his theories of a prehistory without humans (and propensity to explain things away that didn't fit) led to his work becoming very influential to geological thinking, cementing the idea that these catastrophic revolutions were wholly natural and separate from human culture, and that the fossils and bones of extinct animals were 'nature's own history' (Rudwick, 2014: 80). This, along with the discovery of strata and the gradual layering of the sediments that contained these fossils meant that the earth's deep past became legible through the notion of a linear geological history.
\end{abstract}




\section{Unearthing extinction: permafrost and mammoths outside}

Extinction, in the way it is traditionally understood, is a containment. The life of the species has been contained by the passage of time; a cut-off point that implies the creature - in this case the mammoth - remains locked in the past. What the flowing blood does, however, is wrest the mammoth back from her position in deep time. Her body is dead and frozen, her species lost to history, but the presence of blood suggests something more, something livelier. To the scientists who found her body, and many others like her, Buttercup is both the first of her kind and part of a long lineage of other mammoths. Lineage indicates linearity: a gradual and quantitative accumulation of time through mammoth parenthood and their young. Buttercup had parents; her CT scan showed she had given birth to eight children, and her gigantic tusks revealed she had lost one of them before it was weaned, but seven survived beyond that. ${ }^{8}$ Buttercup had left a legacy, and her children had likely gone on to have children of their own. But at the same time, Buttercup's incredible state of preservation, and her bloody existence on the cold slab of the autopsy table in 2014, mean she is out of sync with the rest of her line.

There is a cryopolitical renegotiation that must happen to transfer the mammoth from her bodily form on the tundra to her commodity value as tusks and cells, which is generated by the forces of warming. Whilst the tusk hunters use thawing permafrost to their advantage, there is a sense of anxiety for the scientists as long as the mammoth remains unmolecular, which can only be rectified by the predictability of the cryobank. Preserving specimens in the cryobank - particularly specimens that are already centuries old - suggests a temporal lengthening, a sort of plasticity that can be stretched out indefinitely whilst staying very much the same (Farman, 2018). That global temperatures are rising, and the Arctic is melting is much easier to come to terms with if there's a safeguard of human-controlled freezer systems. It is also reassuring that one might, to borrow Joanna Radin's term, put "life on ice" (2017); perhaps we don't have the solutions for X now, but we might in the future. This pre-emptive cryopolitical shift can only occur once the anxieties of outside melting are rectified by the safety of the human-controlled cryobank, the unpredictability of the mammoth corpse sliced up and placed into sterile test-tubes to be frozen.

This process can be fraught. After returning from the hands-on environment of the Mammoth Museum, I was shown round the rather more sterile cryobank at the Natural History Museum in London by Jacquie, the head of the lab. She recounted to me a breathless story of collecting snail samples in Vietnam and freezing them in the field with dry ice - a process that has a time limit before degradation occurs. An incoming typhoon saw their flight back to London re-routed, and they were delayed at customs due to over-zealous border guards, all the while their precious cargo getting warmer and warmer. She recalled the tense flight back to London:

We drank so much gin on the way home, and then landed in Heathrow eventually, delayed! My husband picked us up from Heathrow and I said: "Put your foot down! Straight to the museum!", pulled up outside the museum here and then they wouldn't let us in! Like 'who are you?'! I'd asked them to warn security that we were coming late but the message hadn't got through. So they wouldn't let me in, and there was another delay while they sorted all that. But we got the boxes back in here and it was still frozen when we opened it. We were leaping around like little maniacal Rumpelstiltskins in joy!

It was touch and go for the specimens in this case, with the threat of warming encroaching further and further. Once inside the temperature-controlled freezer, the conservationists were able to breathe a sigh of relief that they had at least a representative - in the form of genes, or, in this case, snail slime - of the species in its molecular state. It is here we might consider the gene as a boundary object that curates a locus of different actors that produce complex political relationships (Rajan, 2006; Star, 2010). In the mammoth's case, breaking her body down into pieces of flesh and DNA renegotiates the scalar and temporal boundaries of life and death in species conservation and de-extinction (Breithoff and Harisson, 2018; Chrulew, 2017). Here, the added

\footnotetext{
${ }^{8}$ Mammoth tusks are incredible blueprints for the life of their owner. Ringed like trees, a tusk can reveal a mammoth's age, how many children she had, if they reached maturity, and when she entered the menopause (Channel 4, 2014).
} 
dimension of freezing as preservation generates a sense of malleability around the delineated forms of life and death, disruptive agency and human control.

The Mammoth Museum relies on the knowledge of tusk hunters who deliver any well-preserved prehistoric creatures to the museum laboratories (Figure 4). Whilst having tea one day with Semyon, a couple of tusk hunters burst into the room to report a find - they had stumbled across a part of a baby mammoth whilst digging permafrost tunnels. Suddenly, the discussion turned to how best to transport the discovery to the Mammoth Museum's freezer. Yet disturbing mammoth bodies can be a point of tension on the tundra, with different configurations of life and death converging and potentially clashing. Many Indigenous Siberian cosmologies warn that desecrating the grave of mammoths risks terrible luck befalling the person who does such a thing (Arzyutov, 2019; Cohen, 2002; McKay, 2017); elsewhere in Yakutia, I spoke to the wife of a tusk hunter who told me she was worried for him as he had gone to the tusk hunting site without the special beads needed to neutralize the bad fortune of moving a mammoth. Whilst commitment to Siberian belief systems is a complex issue after decades of a Soviet state that forced cultural homogenization upon its Indigenous groups (Grant, 1996; Vitebsky, 2005), the stories I heard from wives largely conveyed disappointment that money was the main motivation in their husbands' activities. Yet it is the demand for ivory that churns the wheel of capital and the production of new commodities in the form of mammoth parts. Whilst the mammoth tusks become prized for their economic potential and the mammoth bodies (or genes) for their scientific potential, both of these work within a capitalist system that affords no space to different ontologies or cosmologies. The melting or blasting of permafrost produces new economies of luxury goods crossing borders, whilst simultaneously paving the way for genetic research that might very well result in Jurassic Park style mammoth petting zoos.

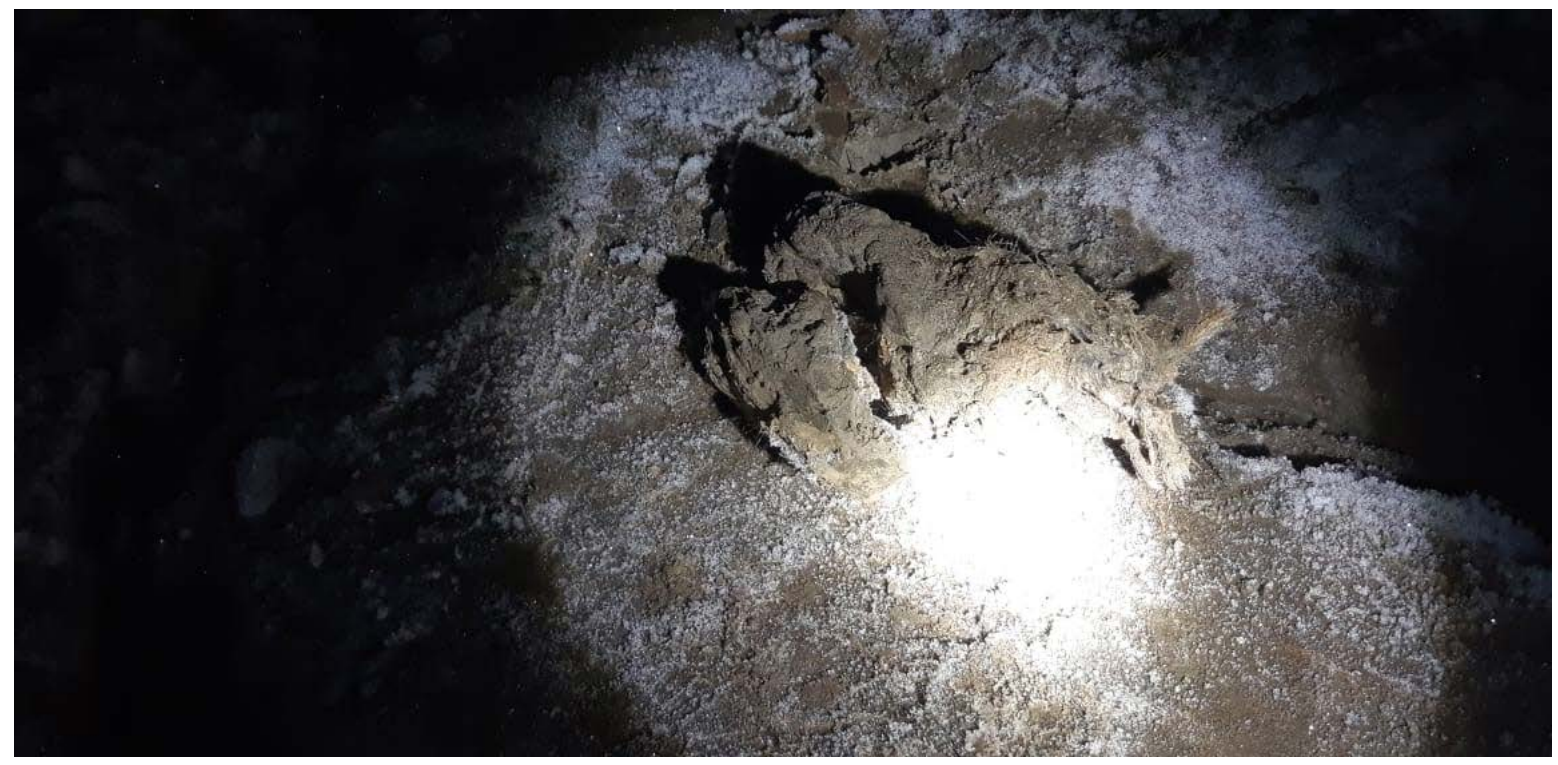

Figure 4: A potentially viable baby mammoth specimen. (The Mammoth Museum, 2018)

At the heart of it, this is a foregrounding of potential life over death. Freezing the molecular mammoth turns the biopolitical into the cryopolitical, whilst the mammoth's status as 'extinct' in the realm of a deextinction laboratory further complicates and unsettles preconceived notions of what life is, where it is located, and how it becomes mobilized in the face of a warming world. Through this, the mammoth becomes an atemporal body, removed from her historical context in the ancient permafrost of the outside and forced into a space through which her genes and tusks become commodities to be stored, swapped, used in an attempt to renegotiate her liveliness as future capital through the cryobank's de-extinction potential. This process of renegotiation through molecularisation, alongside the shift towards a pre-emptive ontopolitics of crisis 
management, becomes solidified inside the human controlled coldness of the cryobank. Now, let us follow her inside.

\section{The cryobank: inside the freezer}

The cryobank at the NHM in London is located down in the basement, far away from the brightly colored exhibits, shiny glass cases, and throngs of tourists. When I finally got there, down seemingly endless corridors, I was met by a couple of largish rooms - one containing a laboratory of sorts, the other housing the freezers. A smaller room adorned with warnings and sensors contained three liquid nitrogen tanks. There were very few people there, and there was a distinct sense of being cut off from the busy museum upstairs. A cursory visitor would have no idea this was here, and there is very little mention of the cryobank on the museum's website; it is certainly not a part of the exhibit and display space. Jacquie had agreed to meet me to answer some of my questions, provided they stayed within the approval of the museum's PR department. I was forbidden from asking anything about possible uses of the cryobank's material for de-extinction, or indeed, any applied conservation measures at all; I was also to stay away from ethical queries and potential geopolitical tensions. The NHM's cryobank is for archiving and research purposes only, so they refused to comment on how this sort of material might be used by more practical conservation bodies. Or, as Jacquie said by way of explanation: "We're not living, we're dead. The deader the better down here!"

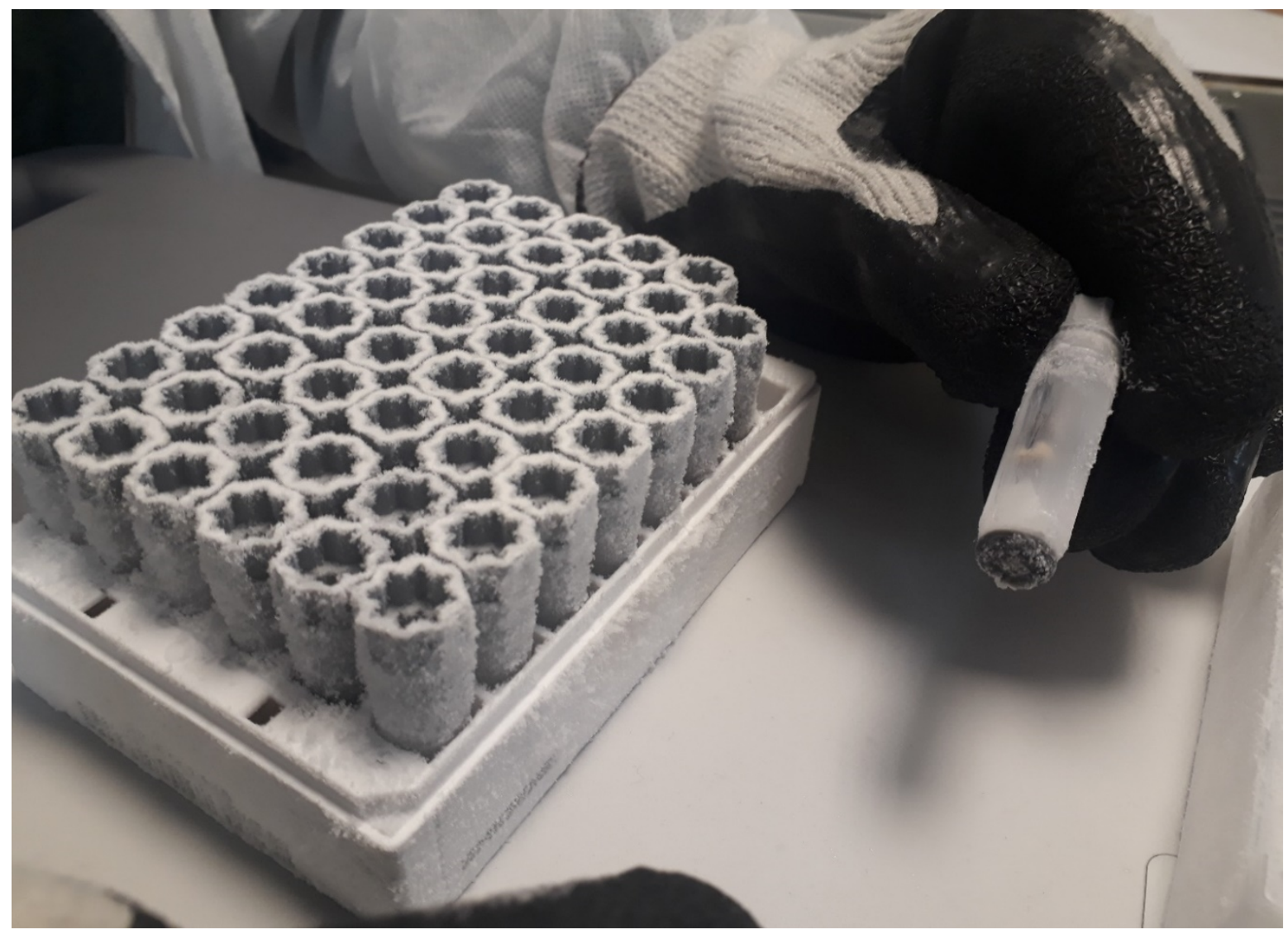

Figure 5: Frozen test tubes used to store genetic material. (author's own, 2019) 
Other cryobanks are more applied and hand-on. The San Diego Frozen Zoo, for example, is actively involved in endangered species conservation through artificial insemination and embryonic stem cells (San Diego Frozen Zoo, n.d.). Then there are the cryobanks actively involved in de-extinction research which search for viable DNA for experimentation. What happens to cryopreserved material as it rejoins the 'defrosted' world generates all sorts of questions regarding the motivations of conservationists and their instruments, alongside the choices made regarding which species get to take on these extremely expensive processes. Indeed, even the method of freezing greatly impacts the quality of preservation. Freezing essentially slows the movement of the organic molecules that make up a sample; the greater the molecular movement, the greater the rate of degradation (Figure 5). The freezer room at the NHM cryobank houses freezers at $-20^{\circ} \mathrm{C}$ and $-80^{\circ} \mathrm{C}$, with the liquid nitrogen tanks keeping temperature at $-196^{\circ} \mathrm{C}$.

With over three quarters of the spots in the cryobank currently occupied, Jacquie faces a lot of tough decisions regarding the value placed on specimens. Provisos that make up a specimen's value are generally the rarity of the species, how useful it might be to scientific research, and the quality of the sample. But a lot of this value is purely economic. Jacquie told me that she essentially has to run the cryobank like a business:

[JACQUIE] So we're quite an old-fashioned institution, but sadly we've been dragged into the sort of business side of things, the cost-per-sample business model type of way of running biobanks, and I'm particularly bad at it! I need to retire and let someone who knows what they're doing take over... We don't say profit, but we have to recover costs, because it's very expensive - our carbon footprint is huge, the electrical costs are huge. There's quite a problem around how we sustain this, who pays for the costs? Keeping things frozen at those ultra-cold temperatures is extremely expensive.

She went on to tell me how government funding is drying up, grants from research institutions are often short term, her staff are retiring and not being replaced - all this has resulted in the cryobank having to recuperate its costs. Only one of the three liquid nitrogen tanks was in use because of the expense of keeping them running; I was expecting an astronomic financial figure, but Jacquie quoted me around $£ 5,000$ (US\$6,881) a year. Her sunny disposition often slipped as she talked about the frustration of trying to do such important work without the help that she needs. She showed me a robot that can reorganize and barcode 96 test tubes at a time, but because it needed to be manually programmed, it remained chronically underused.

When considering artificial cryopreservation in cryobanks and laboratories, we cannot forget these exist within an economic system predicated on surplus value and commodification. The conservation work done by the cryobank has become precision conservation, the molecular 'thread of life' it promises made possible by the freezer's ability to suspend death and revitalize the health of a particular species through tweaks and plugs (Landecker, 2007). This is ice manipulated through the human-dominated systems of the inside, and is similarly underpinned by particular flows of capital and vested interests (Tsing, 2005; 2015). What gets to count as valued life is enclosed by the confines of the cryobank's walls and freezers, the decisions made regarding what to keep configured by stakeholders who will enable Jaquie to break even. The NHM cryobank's official line is one of a 'dead' archive - that it exists as a repository to safeguard genetic material and does not inform applied or future conservation projects. However, the categorization of species through a taxonomy of value (whilst simultaneously requiring cryobank scientists to produce this value through their labor) as the spaces of preservation get ever smaller and more difficult to run are fundamental caveats to what lively commodities the cryobank can produce. Even if a mammoth never emerges from the test tubes archived in the NHM, the potential for life remains, frozen in time, almost indefinitely.

The relocation of life from the organism to the molecular level through laboratory freezing techniques is an attempt at shoring up another layer of control on an increasingly unpredictable Earth. To cryobanks like the NHM, collecting genetic material to store in freezers is a safeguard against the spiraling rate of extinction - a future archive that acts as an organic repository, suspended in stasis until a time at which it might be needed 
for more practical measures (Searle, 2020). This is pre-emptive conservation work that removes the immediacy of the crisis. To de-extinction scientists, the ability to replicate and preserve life through cell cultures and genomes represents an opportunity to not only renegotiate the properties of life, but also to create it. The cryobank becomes a tool through which to extend mastery and control over life, the freezer acting in direct opposition to the unpredictable forces of melting that occurs beyond the bounded and sterile space of the laboratory, where life is suspended within an ambiguous cryopolitical space between being alive and being allowed to die (Radin and Kowal, 2017).

But the cryobank is not the perfectly controllable system it has been designed to be. Notwithstanding being subject to economic systems or freezer breakdowns, the mammoth genes themselves are not the perfectly immutable and predictable objects demanded by the cryobank - particularly if they have become degraded by the forces of thaw and death (Franklin, 2000, 2007; Parry, 2006). What happens once mammoth DNA leaves the cryobank produces new cryopolitical relationships and generates new ethical dilemmas - such as whether a de-extincted mammoth and its CRISPR-rendered genome could be patented by international law (McMahon and Doyle, 2020); or indeed, who is responsible for the creature? Once genetic samples begin to travel along cold chains of scientific and economic value, their liveliness takes on more weight - and more unpredictability. This is where the logic of a pre-emptive ontopolitics begins to break down in the context of the cryobank (Büscher, 2018). De-extinction cannot solely happen in a freezer, and if the mammoth's 'resurrection' is ever a success, her supposedly fungible and controllable form will be - once again - remade anew. If the mammoth does, indeed, go back outside, she will represent an act of crisis conservation - only not for herself, but for another species entirely.

\section{Mammoths out in the world again}

About a month into my stay in Yakutsk, Semyon invited me to a horse autopsy. A tusk hunter had discovered the horse - a prehistoric foal - and the body had been transported back to the Mammoth Museum's freezer to be displayed for a variety of experts, including a team of South Korean geneticists who had just arrived from Seoul. The head of the delegation was Hwang Woo-Suk, a biotechnology expert and veterinarian who made global headlines in 2005 when he claimed to have cloned human embryonic cells - a world first. Whilst the scientific community were grappling with the ethical implications of this, it emerged he had falsified the results of the experiment. Overnight, Hwang went from being dubbed "the pride of Korea" (Scanlon, 2006), to being blacklisted and disgraced, barred from conducting any governmental stem cell research, with his state funding withdrawn.

But Hwang, despite being under criminal investigation, was not finished with embryo research. He retreated into the private sphere, using his veterinary expertise to set up a pet cloning company, charging wealthy patrons - Barbara Streisand is a client - hundreds of thousands of dollars to ensure their precious pets would never 'die.' There was nothing the ethical and rigorous peer review of the scientific community could do about it. A few years later, Hwang began showing up in Yakutsk. Hwang's personal fortune, amassed from his pet cloning business, went towards building a state-of-the-art laboratory at NEFU - something the university could never have afforded otherwise. In exchange, he requested access to any well-preserved specimens of prehistoric creatures found in the permafrost. He wanted to take samples back to his lab in Seoul - Sooam Biotech - to play around with and experiment on ancient DNA, a much greater challenge than dealing with living cells. To put it bluntly, Hwang wants to clone a mammoth.

Hwang also wants to clone the horse lying on the autopsy slab (Figure 6). The creature had been thawing for a while to allow for the sampling to take place on semi-defrosted flesh. The whole room stank; unsurprisingly, prehistoric horse corpses do not smell too great. The results of the radio-carbon dating procedure had come through, and the creature was officially around 42,000 years old, and was between 10-20 days old at the time of death. It was remarkably well preserved, no pieces missing, and every bit recognizable as a horse. Hwang circled the body, prodding at it occasionally, communicating to Semyon his requirements for the visit: he wished to return in the dead of night to collect samples of DNA, which would then be packed 
into an ice box and timed just right so he could dash to his plane back to Seoul, taking the samples with him as hand luggage. This was likely to circumvent Russian laws on exporting biological material through customs, however 'dead' it might be. Regardless, a few months after I left Yakutsk, I noticed that Hwang has made the news - his horse cloning efforts had been unsuccessful.

Buttercup's autopsy had led to similar frustrations, in which her frozen flesh and liquid blood failed to provide the viable cells necessary to expand outwards into a fully realized beast. Both Sooam Biotech and the George Church Lab took samples from her body, but were unable to find any 'useable' DNA. However, both laboratories insist they will be able to successfully resurrect the mammoth at some point in the future. ${ }^{9}$ What exactly happens, therefore, if de-extinction becomes a reality? The Pleistocene Park, of course, is the obvious place for her to go, claiming to offer a ready-made mammoth habitat. Sergey Zimov, the owner of the Park, strides over the tundra sporting a t-shirt sporting the mammoth's likeness, declaring: "I need maybe 50,000 mammoths, but no-one [will] give me so many!" (2019). His reason for wanting mammoths - and, indeed, the whole point of the Park - is not for biodiversity, however, but for the redemption of humanity. The mitigation of permafrost thaw promised by the Park is curated around the idea of 'saving the world', whilst Sergey's son Nikita states: "I personally don't really care about the animals that much", he told me during my visit. "We're trying to create the whole system...I'm not an animal rights activist; I care about humans way more. I have three kids - what I do, I do for them."

It therefore becomes necessary to think through the motivations and power structures underpinning this new form of crisis conservation. The process of molecularization and subsequent de-molecularization of the mammoth through various vested interests is indicative of a grasping for greater control as we hurtle towards a future that portends a lack of it. Just as Landecker (2007) identifies the ability to further manipulate life through laboratory techniques such as tissue culturing and freezing techniques, proposing the de-extinction of the mammoth is an extension of this lust for control, or perhaps hope (Rossi, 2013). Manipulating genes and hybridizing species suggests we might 'swap' (just like CRISPR does) the looming terrible futures of uncertainty for one of benevolent management and stewardship. Whilst the vision of the Pleistocene Park might be to allow the techno-mammoth to wander around and cause havoc in relative freedom, her inextricable history of cryopolitical molecularization and genetic manipulation mean that notions of 'bringing back' are imbued with the meddling hand of the Anthropos. The mammoth's task is no longer to be a mammoth, whatever that might be; now she is tasked with an altogether weightier labor - to right the wrongs of humans who refuse to relinquish control of, and over, life. This is crisis conservation with a twist: the conservation in question is that of the human species through mammoth resurrection, and the existential threat that accompanies the Anthropocene mantle.

The work done by both the Pleistocene Park and the cryobank are conservation practices that seem to contradict each other - the focus on rewilded ecosystems versus the precision conservation of genes and individuals (Adams, 2017) - yet both reveal the fraught tension at the heart of the Anthropocene: that this is an epoch that designates both responsibility and anxiety onto the Anthropos. Crisis conservation - in the mammoth's case at least - is therefore orientated towards the future (rather than the past, which is often the criticism levied at rewilding), underpinned by the cryopolitical potential of suspending death and preserving life on ice (Collard, 2010). It means the crisis can be averted by buying more time, through freezing, to counter a rapidly warming planet and melting Arctic. Cryobanks, despite Jacquie's insistence that her specimens are not engaged in any practical application, exist for the potential to be used for future conservation purposes, whether that be de-extinction or other methods of conservation. The shift towards pre-emptive crisis conservation is encapsulated by the mammoth's commodity value in the cryobank being its potential for future life (Büscher, 2018); this life has now become reconfigured as redemption for humanity, however unlikely the success of the Pleistocene Park may be. To be of value in this world of looming crises and possible apocalypse

\footnotetext{
${ }^{9}$ Just before publication of this article, a new de-extinction organisation called Colossal, backed by US $\$ 15$ million from funders and headed by George Church, announced it would concentrate solely on 'resurrecting' the mammoth in the next 4-6 years (Zimmer, 2021).
} 
means she must curate a better future for the humans that made her. How this works in practice, once the molecular mammoth is returned to a body, once she becomes part of - and can transgress - her ecosystem again, remains to be seen.

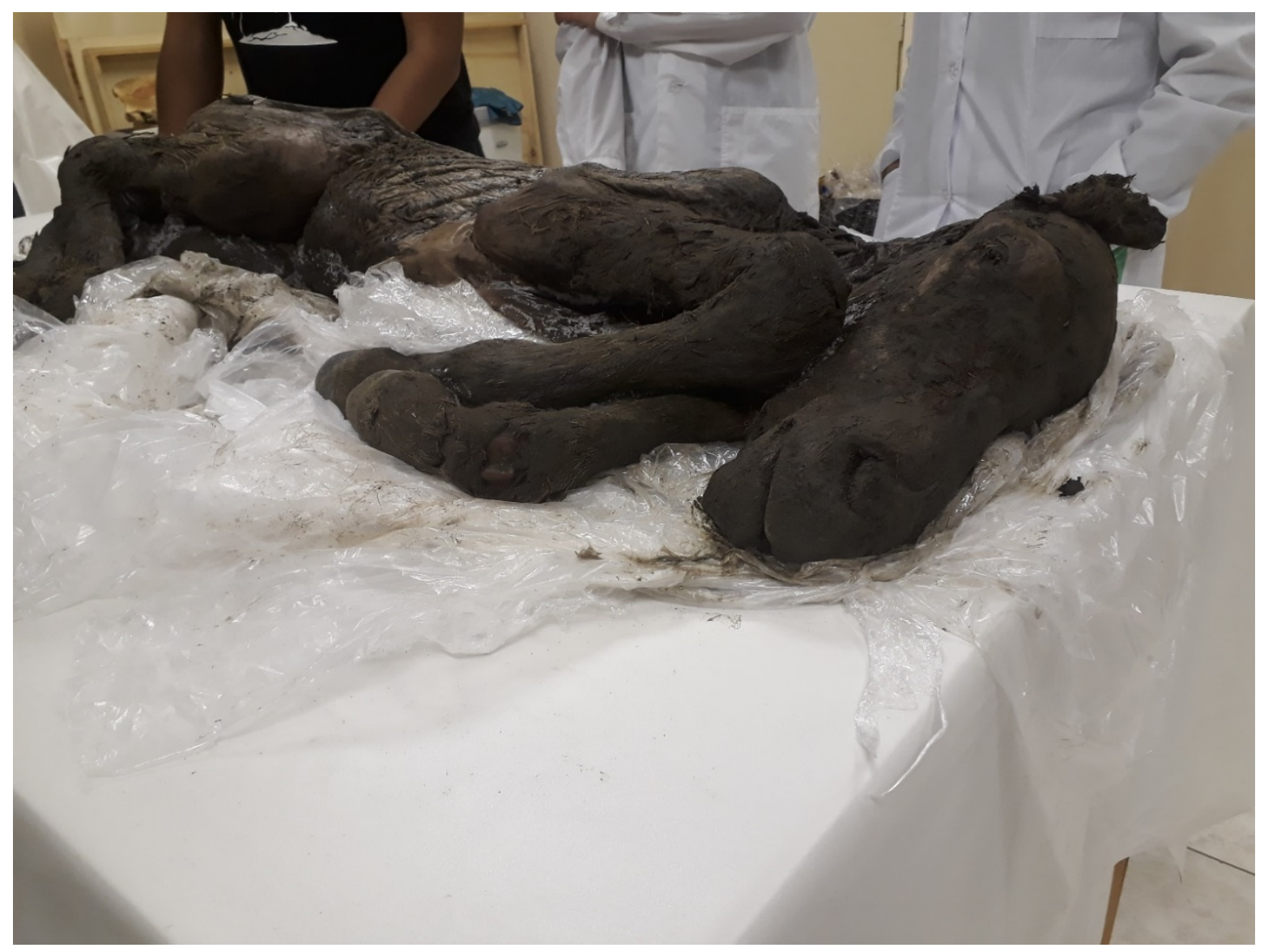

Figure 6: The prehistoric foal. (author's own, 2018)

\section{Conclusion}

What makes a mammoth? Can a mammoth be a cluster of cells, a carved ornament? Can she be resurrected, or will any such attempts only ever be franken-scientific hubris that conjures up the monstrous (Lorimer and Driessen, 2011)? Are the mummified or mounted bodies of historical mammoths all that is left, or does the mammoth take new forms, occupy new spaces or scales, and embody a sort of mutability made possible by flows of things and capital? Bringing life into the equation further complicates things. We question whether life can ever emerge from extinction, when the cryobank makes possible the continuous thread of life through a cryopolitics of suspension, when de-extinction science plays with cells and swaps genes, creating new forms of life through hybridity and genetic manipulation. The tension between the thaw and the freeze troubles these previously fixed identities and definitions, the antagonism of the constant drive towards new extractive opportunities against a backdrop of newly discovered mammoth bodies, fighting against or alongside new economies of tusk trading and DNA swaps. If we return to the idea of crisis conservation as pre-emption (Büscher, 2018), what is it that is being pre-empted here? To conserve means to protect something from destruction; in the mammoth's case, she has already been destroyed, or at least, remade into something entirely 
new. Instead, the crisis conservation found here is that of a cryopolitical sort - that by preserving the ice, the coldness against a backdrop of global warming, we might preserve our very survival on the planet.

The relocation of life from the individual organism to the molecular level through laboratory freezing techniques is an attempt at shoring up another layer of control on an increasingly unpredictable Earth. To cryobanks like the NHM, collecting genetic material to store in freezers is a safeguard against the spiraling rate of extinction - a future archive that acts as an organic repository, suspended in stasis until a time at which it might be needed for more practical measures. To de-extinction scientists such as George Church and Hwang Woo-Suk, the ability to replicate and preserve life through cell cultures and genomes represents an opportunity to not only redraw the boundaries of life, but also to create it. The human-controlled space of the cryobank becomes a tool through which to extend mastery and control over life, the freezer acting in direct opposition to the unpredictable forces of melting that occurs beyond the bounded and predictable space of the laboratory. The thread of life that exists through cell culture across generational, species and organism lines is made possible by freezing, through which life is suspended within an ambiguous cryopolitical space between being 'alive' and being allowed to die. In this sense, it becomes possible to do away with the inherent finitude of life and achieve a sort of immortality - a secular eschatology that abandons the unpredictable notion of a higher power (Farman, 2018), recasting humans as ultimate masters of their own destiny as a way to counter the growing anxiety of apocalypse and extinction.

It is the thawing of permafrost that produces this anxiety of apocalypse; the backdrop of an ongoing sixth great extinction event contextualizes the primal fear of human extinction. The mammoth's potential resurrection crystallizes around the point at which the planet is no longer providing the optimal conditions for human survival and the potential for human technologies to bend those conditions to suit us once more. Once revered in her full form as museum exhibits and scientific specimens, the mammoth has been steadily broken down into her constituent parts until she embodies a molecular commodity, chopped up and put into freezers, squeezed into test tubes and vials, shipped off to places far from her original resting place as biocapital. In becoming molecular, she is imbued with lively future possibility, her cells and genes entering technological spaces that stretch and enlarge, both materially and temporally. The life encased in her cells is temporally translated, both encompassing the vast reaches of her history and possible future, whilst simultaneously suspending time altogether. But beyond the inside boundaries of the cryobank and the cell wall, the unpredictable forces of melting produce ruptures in cryopolitical life - discontinuities which disrupt the linearity of human-controlled time. The life of the molecular mammoth might be safe in the cryobank, but the conditions of her resurrection involve a task: to restore the thawing permafrost that was once her tomb, and to alter the apocalyptic future facing humans in the Anthropocene (Rose, 2017). The very impermanence of permafrost is destructive of both past time and future time in which the human species get to continue on and on, generating a fear that time is running out, and resulting in the desperate push to freeze and control time through the cryobank.

Might a carved ivory ornament encapsulate the messiness of this situation somewhat? This is not to say that these heterogenous scales and temporalities might map onto the surface of a tusk, no matter how intricate - this has been my point in attempting to follow the mammoth, that there is no such neatness. But in the absence of any de-extinct mammoths (yet), these expensive ornaments call to attention both their vast histories and their suspended futures. Many of the carved tusks I saw in Yakutia depicted scenes of Indigenous tribal life, of reindeer herding or fishing (Figure 7). These are not the huge, glittering centerpieces displayed in Chinese homes, but part of a long history of craftmanship honed over centuries, a material archive of living alongside mammoths. Ivory finds, then rare, have now lost much of their mystery as their exposure to the elements is tied up with climate-induced permafrost thaw, illegal economies of trade, and a relentless churn of extraction funded by a Russian state looking to profit from a warming world (Erickson, 2018).

The ivory ornament is not molecular, of course, in the way that the vials and test tubes of the cryobank contain the molecular mammoth, but it represents the almost fungibility of value to be found in de-extinction as crisis conservation. To make a mammoth now requires merely the ability to swap and edit genes with CRISPR, regardless of its specific mammoth histories; similarly, what is valued in Chinese homes is not 
mammoth ivory, but rather the status that ivory of any kind will bring. This is a cryopolitical renegotiation that depends on the melting away of the mammoth's embodied past. Thus, the unspoken crisis at the heart of mammoth de-extinction has little to do with her own species; rather, at a time of geopolitical tensions and extractive designs in a warming Arctic, she represents a potential get-out clause for the possibility of human extinction in the Anthropocene, and the chance to levy control over both life and time - as erroneous as that fantasy may be.

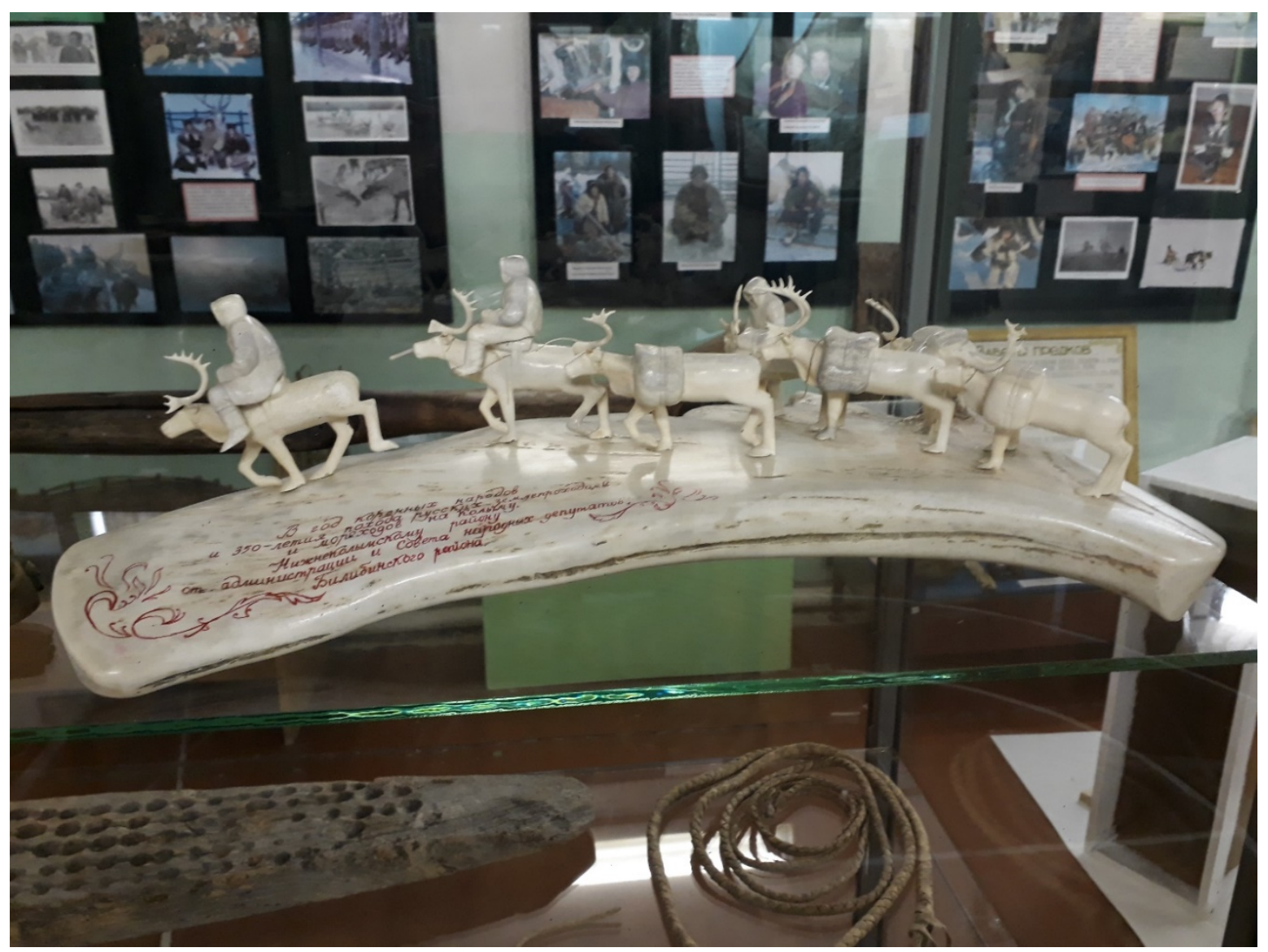

Figure 7: A carved tusk depicts Indigenous reindeer herding in Chersky, Yakutia. (author's own, 2018)

\section{References}

Adams, W.M. 2017. Geographies and conservation I: De-Extinction and Precision Conservation. Progress in Human Geography 41(4): 534-545.

Andersen, R. 2017. Welcome to Pleistocene Park. The Atlantic [online] at https://www.theatlantic.com/magazine/archive/2017/04/pleistocene-park/517779/ (accessed 28/10/20).

Arzyuotov, D.V. 2019. Environmental encounters: Woolly mammoth, indigenous communities and metropolitan scientists in the Soviet Arctic. Polar Record 53(3): 142-153.

Barua, M. 2016. Lively commodities and encounter value. Environment and Planning D: Society and Space 34: 725-744. 
Barua, M. 2017. Nonhuman labour, encounter value, spectacular accumulation: The geographies of a lively commodity. Transactions of the Institute of British Geographers 42: 274-288.

Blue, G. 2015. Multispecies publics in the Anthropocene: From symbolic exchange to material-discursive intra-action. In Human Animal Research Network Editing Collective (eds.) Animals in the Anthropocene: Critical perspectives on non-human futures. Sydney: Sydney University Press. Pp. 165176.

Braverman, I. 2014. Conservation without Nature: The trouble with in situ versus ex situ conservation. Geoforum 51: 47-57.

Bravo, M. 2017. A cryopolitics to reclaim our frozen material states. In J. Radin and E. Kowal (eds.). Cryopolitics: Frozen life in a melting world. Cambridge: MIT Press. Pp. 27-57.

Braun, B. 2007. Biopolitics and the molecularization of life. Cultural Geographies 14(1): 6-28.

Breithoff, E. and R. Harrisson. 2018. From ark to bank: extinction, proxies and biocapitals in ex-situ biodiversity conservation practices. International Journal of Heritage Studies 26: 37-55.

Bridgewater, P. 2016. The Anthropocene Biosphere: Do Threatened Species, Red Lists, and Protected Areas have a future role in nature conservation? Biodiversity Conservation 25: 603-607.

Brook, B.W. and D.M.J.S. Bowman. 2004. The uncertain Blitzkrieg of Pleistocene megafauna. Journal of Biogeography 31(4): 517-523.

Brockington, D., R. Duffy and J. Igoe. 2008. Nature Unbound: Conservation, capitalism and the future of unprotected Areas. London: Routledge.

Brzozowiski, A. 2020. Russia significantly steps up Arctic engagement with new strategy. Euractiv [online] at https://www.euractiv.com/section/arctic-agenda/news/russia-significantly-steps-up-arcticengagement-with-new-strategy/ (accessed 30/08/20).

Büscher, B. 2018. From biopower to ontopower? Violent responses to wildlife crime and the new geographies of conservation. Conservation and Society 16(2): 157-169.

Büscher, B., S. Sullivan, K. Neves, J. Igoe and D. Brockington. 2012. Towards a synthesized critique of neoliberal biodiversity conservation. Capitalism Nature Socialism 23(2): 4-30.

Ceballos, G., P.R. Ehrlich, A.D. Barnosky, A. Garcia, R.M. Pringle and T.M. Palmer. 2015. Accelerated modern human-induced species loss: Entering the Sixth Mass Extinction. Science Advances 1(5): 1-5.

Cavanagh, C.J. 2018. Political ecologies of biopower: Diversity, debates and new frontiers of enquiry. Journal of Political Ecology 25: 402-425.

Chrulew, M. 2017. Freezing the Ark: the cryopolitics of endangered species preservation in J. Radin and E. Kowal (eds.) Cryopolitics: Frozen life in a melting world. Cambridge: MIT Press. Pp. 283-305.

Cohen, C. 2002. The fate of the Mammoth: Fossils, myths and history. Chicago: University of Chicago Press.

Collard, R.C. 2010. Putting animals back together, taking commodities apart. Annals of the Association of American Geographers 104(1): 154-165.

Collard, R.C. and J. Dempsey. 2013. Life for sale? The politics of lively commodities. Environment and Planning A: Economy and Space 45(11): 2682-2699.

Cooper, M.E. 2008. Life as surplus: biotechnology and capitalism in the neoliberal era. Washington: University of Washington Press.

Crist, E. 2013. On the poverty of our nomenclature. Environmental Humanities 3(1): 129-147.

Cunha, D. 2015. The geology of the ruling class? The Anthropocene Review 2(3): 262-266.

Devlin, H. 2017. Woolly Mammoth on verge of resurrection, scientists reveal. The Guardian [online] at https://www.theguardian.com/science/2017/feb/16/woolly-mammoth-resurrection-scientists (accessed 05/09/19).

Edesi, J., J. Tolonen, A.L. Ruotsalainen, J. Aspi and H. Haggman. 2020. Cryopreservation enables long-term conservation of critically endangered species Rubus humulifolius. Biodiversity Conservation 29: 303314. 
Erickson, B. 2018. Anthropocene futures: linking colonialism and environmentalism in an age of crisis. Environment and Planning D: Society and Space 38(1): 111-128.

Farah, N. and J.R. Boyce. 2019. Elephants and mammoths: The effect of an imperfect legal substitute on illegal activity. Development Economics 24(3): 225-251.

Farman, A. 2018. Cryonic suspension as eschatological technology in the secular age. In Antonius C.G.M. Robben (ed.). A Companion to the anthropology of death. Oxford: Wiley. Pp. 307-319.

Fletcher, A.-L. 2020. De-extinction and the genomic revolution: life on demand. Cham: Palgrave-MacMillan.

Foltynova, K. 2020. Sweltering in Siberia: What's behind the heat? Radio Free Europe Radio Liberty [online] at https://www.rferl.org/a/sweltering-in-siberia/30767417.html (accessed 31/08/20).

Fox-Keller, E. 2002. The century of the gene. Cambridge: Harvard University Press.

Franklin, S. 2000. Life itself: global nature and the genetic imaginary. in S. Franklin, C. Lury and J. Stacey (eds.) Global nature, global culture. Thousand Oaks: Sage. Pp. 188-227.

Franklin, S. 2007. Dolly mixtures: the remaking of genealogy. Durham: Duke University Press.

Friese, C. and C. Marris. 2014. Making de-extinction mundane? PLoS Biology 12(3): n.p.

Genesis 2.0 [film]. 2018. Christian Frei (dir.). Bern: Rise and Shine Films.

Grant, B. 1996. In the Soviet house of culture: a century of Perestroikas. Princeton: Princeton University Press.

Gregson, N., M. Crang, F. Ahamed, N. Akhtar R. and Ferdous. 2010. Following things of rubbish value: Endof-life ships, 'chock-chocky' furniture and the Bangladeshi middle class consumer. Geoforum 41(6): 846-854.

Grigoeriev, S.E., D.C. Fisher, T. Obadă, E.A. Shirley, A.N. Rountrey, G.N. Savvinov, D.K. Garmaeva, G.P. Novgorodov, M.Yu. Cheprasov, S.E. Vasilev, A.E. Goncharov, A. Masharskiy, V.E. Egorova, P.P. Petrova, E.E. Egorova, Y.A. Akhremenko, J. van der Plicht, A.A. Galanin, S.E. Fedorov, E.V. Ivanov and A.N. Tikhonov 2017. A woolly mammoth (Mammuthus primigenius) carcass from Maly Lyakhovsky Island (New Siberian Islands, Russian Federation). Quaternary International 445: 89-103.

Haraway, D. 1988. Situated knowledges: the science question in feminism and the privilege of partial perspective. Feminist Studies 14(3): 575-599.

Hathaway, M. 2015. Wild Elephants as actors in the Anthropocene. In Human Animal Research Network Editing Collective (eds.) Animals in the Anthropocene: critical perspectives on non-human futures. Sydney: Sydney University Press. Pp. 221-242.

Hendrick, P.W. 2001. Conservation genetics: where are we now? Trends in Ecology and Evolution 16: 629636.

Ice Age: Return of the Mammoth [Documentary]. 2019. Nick Clarke Powell (dir.). UK: Channel 4.

IUCN Red List of Threatened Species [online] at https://www.iucnredlist.org/ (accessed 25/02/20).

Johnson, C.N., A. Balmford, B.W. Brook, J.C. Buettel, M. Galetti, L. Guangchan and J.M. Wilmshurst. 2017. Biodiversity losses and conservation responses in the Anthropocene. Science 356(6335): 270-275.

Kay, L. 2000. Who wrote the book of life? A history of the genetic code. Stanford: Stanford University Press.

Lambek, M. 2016. After Life. In V. Das and C. Han (eds.). Living and dying in the contemporary world. Berkeley: University of California Press. Pp. 629-647.

Landecker, H. 2007. Culturing life: How cells became technologies. Cambridge: Harvard University Press.

Landweber, L. and A. Dobson (eds.). 1999. Genetics and the extinction of species: DNA and the conservation of biodiversity. Princeton: Princeton University Press.

Lermen, D., B. Blomeke, R.K. Browne, A. Clarke, P.W. Dyce, T. Fixemer, G. Fuhr, W.V. Holt, K. Jewgenow, R.E. Lloyd, S. Lotters, M. Paulus, G. McGregor-Reid, D.H. Rapoport, D. Rawson, J. Ringleb, O.A. Ryder, G. Sporl, T. Schmitt, M. Veith and P. Muller. 2009. Cryobanking of viable biomaterials: implementation of new strategies for conservation purposes. Molecular Ecology 18: 1033-1033.

Lorimer, J. 2012. Multinatural geographies for the Anthropocene. Progress in Human Geography 36(5): 593612. 
Lorimer, J. and C. Driessen. 2013. Bovine biopolitics and the promise of monsters in the rewilding of Heck Cattle. Geoforum 48: 249-59.

L'Hypothese de Zimov [Documentary]. 2020. Denis Sneguirev (dir.). France: Arte France.

Mammoth [Documentary]. 2017. Grant Slater (dir.). USA: The Atlantic.

Masumi, B. 2015. Ontopower: War, powers, and the state of perception. Durham: Duke University Press.

McKay, J.J. 2017. Discovering the Mammoth: A tale of giants, unicorns, ivory, and the birth of a new science. New York: Pegasus Books.

Mendes, M. 2017. Molecular colonialism. In M. Mendes (ed.) Matter Fictions. Berlin: Sternberg Press. Pp. 127-140.

Milkoreit, M. 2017. Imaginary politics: Climate change and the making of the future. Elementa: The Science of the Anthropocene 5: 62-75.

Moore, L. 2011. The neoliberal elephant: Exploring the impacts of the trade ban in ivory on the commodification and neoliberalisation of elephants. Geoforum 42(1): 51-60.

Myers, S.L. 2017. Weaning itself from elephant ivory, China turns to mammoths. The New York Times [online] at https://www.nytimes.com/2017/08/06/world/asia/china-elephant-mammoth-ivory.html (accessed 25/02/20).

Palkopoulou, E., S. Mallick, P. Skoglund, J. Enk, N. Rohland, H. Li, A. Omrak, S. Vartanyan, H. Poinar, A. Götherström, D. Reich L. and L. Dalen. 2015. Complete genomes reveal signatures of demographic and genetic declines in the Woolly Mammoth. Current Biology 25(10): 1395-1400.

Parry, B. 2004. Trading the genome. New York: Columbia Press.

Parry, B. 2006. New Spaces of biological commodification: the dynamics of trade in genetic resources and 'bioinformation.' Interdisciplinary Science Reviews 31(1): 19-31.

Pertoldi, C., R. Bijlsma and V. Loeschcke. 2007. Conservation genetics in a globally changing environment: Present problems, paradoxes and future challenges. Biodiversity and Conservation 16: 4147-4163.

Putin, V. 2020. О Стратегии развития Арктической зоны Российской Федерации и обеспечения наииональной безопасности на период до 2035 года [On the strategy for the development of the Arctic Zone of the Russian Federation and ensuring national security for the period until 2035]. Government of the Russian Federation [online] at https://www.arctic2035.ru/ (accessed 30/04/2021).

Radin, J. 2017. Life on ice: A history of new uses for cold blood. Chicago: University of Chicago Press.

Radin, J. and E. Kowal (eds.) 2017. Cryopolitics: Frozen life in a melting world. Cambridge: MIT Press.

Raising the Mammoth [Documentary]. 2000. Jean-Charles Denieau (dir.). France: Discovery Channel.

Rajan, Sunder K. (2006). Biocapital The constitution of postgenomic life. Durham: Duke University Press.

Revive and Restore [online] at https://reviverestore.org/ (accessed 29/10/20).

Rose, D.B. 2017. Reflections on the zone of the incomplete. In Radin, J. and E. Kowal (eds.). Cryopolitics: Frozen life in a melting world. Cambridge: MIT Press. Pp. 145-155.

Rose, N. 2001. The politics of life itself. Theory, Culture \& Society 18(6): 1-30.

Rose, N. 2007. The politics of life itself: Biomedicine, power and subjectivity in the twenty-first century. Princeton: Princeton University Press.

Rossi, J. 2013. The socionatural engineering of reductionist metaphors: A political ecology of synthetic biology. Environment and Planning A 45: 1127-1143.

Rudwick, M.J.S. 2005. Bursting the limits of time: The reconstruction of geohistory in the age of revolution. Chicago: University of Chicago Press.

Rudwick, M.J.S. 2014. Earth's deep history: How it was discovered and why it matters. Chicago: University of Chicago Press.

San Diego Frozen Zoo. n.d. How we're helping to save the White Rhino [online] at https://institute.sandiegozoo.org/species/white-rhino (accessed 16/07/20). 
Scanlon, C. 2006. Korea's national shock at scandal. BBC [online] at http://news.bbc.co.uk/1/hi/world/asiapacific/4608838.stm (accessed 05/09/19).

Sepkoski, D. 2020. Catastrophic thinking: Extinction and the value of diversity from Darwin to the Anthropocene. Chicago: University of Chicago Press.

Shapiro, B. 2016. Pathways to de-extinction: How close can we get to resurrection of an extinct species? Functional Ecology 31(5): 996-1002.

Shukin, N. 2009. Animal capital: Rendering life in biopolitical times. Minneapolis: University of Minnesota Press.

Siberian Times Reporter. 2019. Scientists 'confident' that they can extract cells to clone 42,000 year old extinct foal. The Siberian Times [online] at https://siberiantimes.com/science/casestudy/news/scientistsconfident-that-they-can-extract-cells-to-clone-42000-year-old-extinct-foal/ (accessed 05/09/19).

Star, S.L. 2010. This is not a boundary object: Reflections on the origin of a concept. Science, Technology and Human Values 35(5): 601-617.

Thacker, E. 2005. The Global Genome: Biotechnology, politics, and culture. Cambridge: MIT Press.

Tsing, A.L. 2005. Friction: An ethnography of global connection. Princeton: Princeton University Press.

Tsing, A.L. 2015. The Mushroom at the end of the world: On the possibility of life in capitalist ruins. Princeton: Princeton University Press.

van Dooren, T. 2009. Banking Seed: Use and value in the conservation of agricultural diversity. Science as Culture 18(4): 373-395.

van Dooren, T. 2017. Banking the forest: Loss, hope and care in Hawaiian conservation. In J. Radin and E. Kowal (eds.). Cryopolitics: Frozen life in a melting world. Cambridge: MIT Press. Pp. 259-282.

Vitebsky, P. 2005. Reindeer People: Living with animals and spirits in Siberia. London: Harper Perennial.

Waldby, C. 2000. The visible human project: Informatic bodies and posthuman medicine. London: Routledge.

Weiss, S. 2019. The climate crisis has sparked a Siberian mammoth tusk gold rush. Wired [online] at https://www.wired.co.uk/article/mammoth-tusk-hunters-russia-china (accessed 25/02/20).

Woolly Mammoth: The autopsy [Documentary]. 2014. Nick Clarke Powell (dir.). UK: Channel 4.

Worrall, S. 2017. We could resurrect the Woolly Mammoth. Here's how. National Geographic [online] at https://www.nationalgeographic.com/news/2017/07/woolly-mammoths-extinction-cloning-genetics/ (accessed 05/09/19).

Zimmer, C. 2021. A new company with a wild mission: Bring back the Woolly Mammoth. The New York Times [online] at https://www.nytimes.com/2021/09/13/science/colossal-woolly-mammoth-DNA.html (accessed 22/09/21). 